Cornell Law Library

Scholarship@Cornell Law: A Digital Repository

Cornell Law Faculty Working Papers

Faculty Scholarship

$1-1-2004$

\title{
Putting the Democracy in Democracy and Distrust: The Coherentist Case for Representation Reinforcement
}

Michael C. Dorf

Cornell LawSchool, michaeldorf@cornell.edu

Follow this and additional works at: http://scholarship.law.cornell.edu/clsops_papers

Part of the Constitutional Law Commons

\section{Recommended Citation}

Dorf, Michael C., "Putting the Democracy in Democracy and Distrust: The Coherentist Case for Representation Reinforcement" (2004). Cornell Law Faculty Working Papers. Paper 73.

http://scholarship.law.cornell.edu/clsops_papers/73

This Conference Proceeding is brought to you for free and open access by the Faculty Scholarship at Scholarship@Cornell Law: A Digital Repository. It has been accepted for inclusion in Cornell Law Faculty Working Papers by an authorized administrator of Scholarship@Cornell Law: A Digital Repository. For more information, please contact jmp8@cornell.edu. 


\title{
Putting the Democracy in Democracy and Distrust: The Coherentist Case for Representation Reinforcement
}

\author{
Michael C. Dorf
}

[Draft to be presented at Yale Law School Memorial Symposium in honor of John Hart Ely]

\section{Introduction}

Nearly a quarter of a century after its publication, Democracy and Distrust ${ }^{1}$ remains the single most perceptive justificatory account of the work of the Warren Court and modern constitutional law more broadly. Yet, the continuing influence of John Hart Ely's process theory of American constitutional law may seem surprising, given that the account has been incisively criticized as both too limited and too sweeping. Beginning with Laurence Tribe's "Puzzling Persistence of Process-Based Constitutional Theories" and culminating in the work of Ronald Dworkin and others, critics have argued that the representation-reinforcing approach to interpreting the Constitution is no less laden with controversial value judgments than other, more openly substantive methods, and that therefore, judicial review ought not to be restricted in the way that Ely thought it should be. ${ }^{2}$ From the other side, those that Ely called "interpretivists" have invoked (more or less) the same set of arguments as a basis for concluding that the

\footnotetext{
${ }^{*}$ Michael I. Sovern Professor of Law, Columbia University School of Law. The author gratefully acknowledges the helpful suggestions and comments of Sherry Colb, James Fleming, Samuel Issacharoff, and Richard Primus. Thanks to Adam Schleifer for excellent research assistance and more.

${ }^{1}$ John Hart Ely, Democracy and Distrust: A Theory of Judicial Review (1980).

${ }^{2}$ See Laurence H. Tribe, The Puzzling Persistence of Process-Based Constitutional Theories, 89 Yale L.J. 1063, 1067-72 (1980); Ronald Dworkin, Freedom's Law: The Moral Reading of the American Constitution 76-81 (1996) (arguing that the distinction between enumerated and unenumerated rights, which is central to Ely's theory, is incoherent).
} 
Constitution's open-ended provisions should be given neither substantive nor procedural content apart from what is narrowly entailed by the original understanding of its framers and ratifiers. ${ }^{3}$

In light of these mirroring critiques, what accounts for the staying power of Democracy and Distrust? The answer, to which Ely himself points in the opening pages of the book, is the popularity of democracy. "We have as a society from the beginning," he writes, "and now almost instinctively, accepted the notion that a representative democracy must be our form of government. ${ }^{4}$ By making more-or-less-majoritarian democracy the centerpiece of his account of judicial review, Ely trades on this deeply rooted instinct. Throughout Democracy and Distrust, he invokes "the basic democratic theory of our government" as the standard against which an approach to judicial review should be measured.

Although Ely ultimately attaches weight to the value of democracy because of its longstanding and continuing acceptance by the People, the core of his affirmative argumentwhich appears in Chapter Four - purports to derive that value principally from the constitutional text and structure: In barely fourteen pages he establishes that most of the Constitution consists of structural provisions about offices, elections and so forth, going on to explain that even some of the relatively few provisions setting forth individual rights might also best be understood as structural or procedural. ${ }^{6}$ Having thus derived the democratic criterion from the Constitution's text and structure, Ely devotes the balance of Democracy and Distrust to explaining how that principle can be used to guide judicial interpretation of open-ended provisions like the Ninth

\footnotetext{
${ }^{3}$ See, e.g., Robert H. Bork, The Tempting of America: The Political Seduction of the Law 143-160 (1990).

${ }^{4}$ Ely, supra note 1 , at 5 .

${ }^{5}$ Id. at 45 .

${ }^{6}$ See id. at $88-101$
} 
Amendment and the Fourteenth Amendment's Equal Protection and Privileges or Immunities Clauses. $^{7}$

So far as getting the project off the ground, however, the text and structure do not bear the weight that Ely appears to place on them in Chapter Four. Given the Constitution's manifest interest in fracturing the authority of any actor or institution to speak on behalf of the People as a whole, one might at least as readily infer the opposite master principle of limited government, a principle that is also furthered by the document's substantive rights provisions. If majoritarian democracy were really the guiding principle that Ely claims, there would seem to be little need for a written Constitution at all, except perhaps to specify, as in pre-Human Rights Act England under the classical Diceyan conception, that the national legislature is sovereign. ${ }^{8}$

In any event, no master principle—not majoritarian democracy, limited government, individual liberty, equality, free enterprise, or any other principle — can plausibly be made to stand for the whole of the Constitution. It is the purpose of the document to frame a government that serves multiple, often conflicting aims.

If Democracy and Distrust thus sets forth an implausible (or perhaps more accurately, an overstated) positive account of the Constitution, it nonetheless seems to provide an attractive normative account of judicial review. The central principle of the Constitution is not democracy (because there is no single central principle), but the central problem facing a life-tenured judiciary charged with enforcing open-ended language like that found in the Fourteenth Amendment is one of reconciling their job with democracy. That is not because the very concept

\footnotetext{
${ }^{7}$ See id. at 101-83.

${ }^{8}$ And of course, England seemed to get along fine without even that sort of ultra-minimalist written constitution. I say "seemed" because one can question whether England ever truly had a system of parliamentary (as opposed to popular) sovereignty. See generally Rivka Weill, Dicey Was Not Diceyan, 62 Cambridge L.J. 474. One can also question whether Dicey himself believed in the simpler account. See id. $492-493$
} 
of democracy requires that all important decisions be made entirely by politically accountable bodies; it is because in the absence of some set of limiting principles to govern interpretation of the Constitution's open-ended provisions, there would be nothing to stop courts from entirely supplanting politically accountable bodies; and such a state of affairs would be inconsistent with a Constitution that makes popular sovereignty an important principle, perhaps the most important principle (though not the single central principle).

The normative argument I have just sketched on Ely's behalf is nonetheless still partly positive. If a constitution manifested no concern with self government—if for example, it set forth judicially enforceable limits on government power without empowering the People, as in, say, a system of limited benign dictatorship - then a theory of representation reinforcement would have little purchase as an account of how the judiciary ought to enforce that constitution. So the fact that the actual Constitution embraces popular rule does indeed play a substantial role in the argument for representation-reinforcing and only representation-reinforcing judicial review of the open-ended provisions.

But, to repeat, the argument ultimately succeeds because of the widespread normative appeal of democracy. As Ely explains in the book's opening passages, in the modern world we almost reflexively value self-government. Thus, for constitutional lawyers, the Court has a counter-majoritarian difficulty; Congress does not have a "counter-individual" difficulty; yet if we took limited government as our starting point, we might well see matters differently. To be sure, we as a People greatly value limits on government power as well as democracy, but, to use Madison's phrase, judicial delineation and enforcement of these limits is at best "auxiliary" to government's "dependence on the people." So democracy turns out to be important both for its

\footnotetext{
${ }^{9}$ The Federalist No. 51, 322 (James Madison) (Clinton Rossiter ed., 1961). I say "at best" because when Madison wrote these words he was still committed to the view that, given the strategy of enumerated
} 
own sake — so that the People can carry out their projects—and for limiting government's potential excesses.

Or at least that is the largely unspoken piece of Ely's argument: that democracy is good. Stated that way (which, of course, is not how Ely states it), the point sounds banal, and it is. But is it even true? Is democracy good? Democracy and Distrust argues that democracy is not—or at least is not inevitably—self-sustaining; it may need the aid of an unelected judiciary armed with a broadly worded constitution. The book takes for granted the more basic point that democracy is worth sustaining.

I am not suggesting that Democracy and Distrust is a flawed work for its failure to make an argument for the value of democracy. Ely was perfectly well justified in assuming that his audience would see its value. But the value of democracy - as opposed to monarchy, autocracy, theocracy and other systems of government—is not universally acknowledged, and more importantly, even among those who value it, there are important differences about how and how much to value the popular will. Other than the fact that most of his audience would share his view, what justified Ely—and Bickel and others—in casting democratic values as central to our constitutional system, such that the framing of Democracy and Distrust as a response to a counter-majoritarian difficulty seemed and still seems perfectly natural?

This Article suggests a tentative answer by forging a link between Ely's work and that of coherentists like Ronald Dworkin and John Rawls. Critics of Rawls's A Theory of Justice ${ }^{10}$ argued that where Rawls purported to derive universal principles of political justice, he in fact

powers, the Constitution did not need to include a Bill of Rights. The "auxiliary" precautions to which he referred in Federalist 51 were the structural mechanisms limiting democracy that comprised the original Constitution. In the course of the ratification debate, however, Madison came to see how individual rights could serve the same purpose. See Laurence H. Tribe \& Michael C. Dorf, On Reading the Constitution 6 (1991).

${ }^{10}$ John Rawls, A Theory of Justice (1971). 
simply affirmed principles of liberal democracy common to the Twentieth Century West. ${ }^{11}$ In his successor volume, Political Liberalism, Rawls acknowledged the socially and historically contingent character of his political principles, but denied that this contingency rendered these principles any less principles of justice. ${ }^{12}$

Ely could have made a parallel maneuver. He might have argued that although representation reinforcement is not simply entailed by the Constitution as a matter of text and structure, it is nonetheless the best account of our collective self-understanding of the function of judicial review in a constitutional democracy. Indeed, as I have noted, there are many passages in Democracy and Distrust that suggest that Ely himself understood his account of American judicial review as contingent in just the same way that Rawls came to acknowledge that his account of liberal democracy was. This Article pulls together these "contingentist" strands to fashion — and then critique - a prolegomenon to a work that would be to Democracy and Distrust what Political Liberalism is to A Theory of Justice.

Part I describes how, under the conventional reading, Democracy and Distrust trades on the reader's sympathy for democracy. It concludes that someone who does not come to the book

\footnotetext{
${ }^{11}$ See, e.g., Alasdair MacIntyre, After Virtue (1981) (questioning the possibility of Rawlsian "constructivist" argument absent agreement upon a conception of the good); Michael J. Sandel, Liberalism and the Limits of Justice 28 - 46 (1982) (disagreeing with the picture of human identity that Rawls's theory purportedly assumes - a human identity artificially isolated from community influences and obligations); Michael Walzer, Spheres of Justice (1983) (rejecting Rawls's effort to root political justice in a very small number of abstract principles). For the feminist version of the argument, see, e.g., Seyla Benhabib, Situating the Self: Gender, Community and Postmodernism in Contemporary Ethics 2-3 (1992) (critiquing Rawls along with Enlightenment reasoning more generally); Margaret Jane Radin, The Pragmatist and the Feminist, 63 S. Cal. L. Rev. 1699, 1713 (1990) (associating the values advanced by Rawls with masculinity).

${ }^{12}$ See John Rawls, Political Liberalism xviii (paperback ed., 1993) (rejecting "the so-called Enlightenment project of finding a philosophical secular doctrine, one founded on reason and yet comprehensive" in favor of "work[ing] out a conception of political justice for a constitutional democratic regime that the plurality of reasonable doctrines [held by its diverse citizens] might endorse.").
} 
with that sympathy will not find enough in the Constitution itself for Ely's argument to be successful.

Part II sets forth an "interpretivist" "13 version of Ely's argument along the same lines as, albeit with content that differs from, the sort of interpretivist account of constitutional practice given by Ronald Dworkin. In arguing that Ely's theory is best read as an interpretive theory, I make no claim to novelty; I have no doubt that Ely himself would have readily accepted that his account was intended to be interpretivist. My claim is simply that recognizing the interpretivist character of Ely's argument enables us to see how widespread public acceptance of democratic principles can count in favor of those democratic principles in a non-circular fashion. However, calling attention to the interpretivist character of Ely's argument also calls attention to certain powerful objections to interpretivism, which Part II considers in some detail. The Part concludes by adapting the solution Rawls gave to an objection similar to the most serious of the objections offered against Ely's theory. The solution is "pragmatic" in the way that William James and Richard Rorty are pragmatic philosophers.

Part III points to, and then elaborates, a further, and apparently puzzling, link between Rawls and Ely: Both advocate a system of government in which the basic political frameworkwhat Rawls called the "basic structure" and for Ely simply the Constitution-contains largely procedural guarantees that are thinner than the substantive values individual members of the society hold. This feature of Democracy and Distrust is puzzling because, as indicated by the subtitle ("A Theory of Judicial Review"), the book sets forth an approach that judges should use

\footnotetext{
${ }^{13}$ I am using "interpretivism" here to mean an account of a practice that is interpretive rather than purely descriptive or prescriptive. This use of the word should not be confused with Ely's wholly different use of the term "interpretivism" to mean something like "textualism" or "originalism." See Ely, supra note 1, at 1 . To avoid confusion, throughout this article, except where otherwise noted, I use "interpretivist" in the first sense rather than in Ely's sense of the word.
} 
to interpret the Constitution we have; it would seem to have no obvious implications for the question of what constitution makers should put in a constitution in the first place. Yet, Ely

plainly believes that a well-constructed constitution should be almost entirely "procedural." ${ }^{14}$ I explain away the puzzle by showing how Ely's sympathy for democracy does indeed have implications for constitution writing as well as constitution reading. I then ask whether Ely's position can withstand critical scrutiny, given that some substantive provisions, such as our Thirteenth Amendment's prohibition on slavery, seem to be appropriately included in a constitution. Part III concludes with a tentative defense of Ely's views that emphasizes the pragmatist elements of his thought.

\section{Is Majoritarian Democracy a Principle to Guide Constitutional Interpretation?}

The core of Democracy and Distrust appears to consist of a two-step argument: (1) the central value of the Constitution is majoritarian democracy; and therefore (2) in searching for limits on how to interpret the open-ended provisions of the Constitution, judges should be guided by the principle of majoritarian democracy. It hardly takes a professional logician to notice that (2) does not follow inexorably from (1). Even if we grant that the Constitution is mostly or perhaps almost entirely concerned with establishing the ground rules for self-government in the American Republic, it would still be possible that the few open-ended provisions should be interpreted more substantively.

But I want to put that objection aside for now, partly because Ely has a response to it: Sure, he might say, there is no logical inconsistency between establishing a basically majoritarian system with substantive side constraints whose content is to be found by Platonic

\footnotetext{
${ }^{14}$ Ely, supra note 1, at 99-101.
} 
Guardians, but if, over time, the Guardians, pursuant to their ostensibly limited role of enforcing the side constraints, increasingly remove the most vital questions from the domain of the voters, then the point of the Constitution's majoritarian provisions has been lost, and accordingly, we ought to reject at the outset an interpretation of the open-ended provisions that authorizes the Guardians to proceed down that path. Even if we assume this response is persuasive, ${ }^{15}$ however, there remains the problem of establishing proposition (1) - that the Constitution's central value is majoritarian democracy.

I noted in the Introduction that Ely attempts to establish proposition (1) in a brief fourteen pages in Chapter Four. That was an exaggeration. He actually devotes exactly one sentence to the matter, albeit a longish sentence punctuated with dashes and a semi-colon. He says: "I don't suppose it will surprise anyone to learn that the body of the original Constitution is devoted almost entirely to structure, explaining who among the various actors - federal government, state government; Congress, executive, judiciary - has authority to do what, and going on to fill in a good bit of detail about how these persons are to be selected and to conduct their business."16 The rest of the argument in Chapter Four explains how even most of the seemingly substantive provisions in the original Constitution and subsequent amendments can be seen as essentially procedural. ${ }^{17}$

Its brevity aside, what should we make of Ely's argument from text and structure? Not much, I'm afraid. For one thing, the point is a non sequitur. Ely seems to be saying that because

\footnotetext{
${ }^{15}$ I tend to think it is not. In the post-Lochner era, even the most ambitious programs of judicial review still leave in the hands of elected officials such decisions as the size and distribution of taxes, whether and when to go to war, and most questions of macroeconomic policy. For an unelected judiciary to take questions like abortion, affirmative action, and school prayer off the public agenda thus hardly renders elections pointless.

${ }^{16}$ Ely, supra note 1, at 90 .

${ }^{17}$ See id. at $90-101$.
} 
nearly all of the words of the Constitution are used to set the ground rules for democracy, that's what the Constitution is fundamentally about. Yet that hardly follows. Suppose that a constitution went into great detail specifying all the offices of government, their powers, and so forth, and then included, as its final provision, the following: The fundamental principle of this government is respect for the dignity of all persons, and the High Court shall accordingly void all laws and other official acts inconsistent with dignity of the person. In the face of such language, it would be hard to argue that the prolix provisions establishing the ground rules implicitly set forth an even more fundamental principle than the express fundamental principle of human dignity. Yet, given that something like my imaginary "dignity provision" is on offer as an interpretation of the Ninth Amendment and the Privileges or Immunities Clause, Ely cannot establish the greater fundamentality of the procedural provisions simply by pointing to their greater numerosity.

Indeed, I am tempted to think that the opposite is true- - that to the extent that the procedural provisions go on at length, they "partake of the prolixity of a legal code,"18 which, if John Marshall is to be believed, makes them less rather than more fundamental. The short plain statements of principle, like the First Amendment and Fourteenth Amendment's Section 1, have the ring of fundamentality because of, not despite, their brevity. The notion that brevity, not prolixity, connotes fundamentality, permeates our legal culture. ${ }^{19}$

In any event, even if we count the length and number of procedural provisions as making out a prima facie case of their importance, it hardly follows that what they make fundamental is majoritarian democracy. I am certainly not the first person to notice that the form of

\footnotetext{
${ }^{18}$ McCulloch v. Maryland, 4 Wheat. 316, 407 (1819).

19 Thus, the terse "Sherman Act has long been analogized in its generality and flexibility to the Constitution ...." Thomas E. Kauper, The Report of the Attorney General's National Committee to Study the Antitrust Laws: A Retrospective, 100 Mich. L. Rev. 1867, 1871 (2002).
} 
representative government that these provisions establish seems designed to frustrate, rather than facilitate, the ability of a national majority to enact its will into law; bicameralism, separation of powers, federalism, and the difficulty of constitutional amendment are all essentially permanent features of American government that make the enactment of new policies in the United States much more difficult than in parliamentary systems of government. ${ }^{20}$

To be sure, in its time, the original United States Constitution was the most democratic in the world, and over time, American government has become more democratic in two ways: provisions like the Seventeenth Amendment (substituting direct election of Senators for state legislative appointment) have tied the People's representatives closer to the People, while provisions like the Fifteenth and Nineteenth Amendments have greatly widened the scope of the franchise. But all of this simply shows that whatever sorts of decisions are committed to decision by popularly elected officials, using whatever means of making such decisions the Constitution establishes, the officials have become more accountable to a more broadly defined People. It is not at all clear that a widespread franchise and direct elections have any bearing on the question of what issues the People may properly decide.

Thus, democracy as an interpretive über-principle cannot be derived from the Constitution's text and structure standing alone. But perhaps we should view "the Constitution" as including the interpretive gloss that has been placed on it over the years. After all, judges and constitutional lawyers routinely consult constitutional doctrine, evidence of the original understanding, post-enactment history, and ethical and prudential considerations along with-

${ }^{20}$ See, e.g., Charles A. Beard, An Economic Interpretation of the Constitution of the United States 189216 (Free Press 1986) (1913) (arguing that the difficulty of lawmaking under the American Constitution was a deliberate product of fiscally conservative counter-revolutionary forces at the 1787 Convention); Robert A. Dahl, How Democratic is the American Constitution? 143, 143 - 46 (2001) (answering, in essence, "not very" to question posed by book's title); Woodrow Wilson, Congressional Government: A Study in American Politics (1885) (preferring parliamentary government to separation of powers under the American Constitution because of the former's greater flexibility). 
indeed sometimes before consulting — text and structure. ${ }^{21}$ At least with respect to original understanding and doctrine, Ely himself seems committed to this strategy. He reproduces an extended quotation from Federalist 51 to show Madison's commitment to interest-group pluralism, ${ }^{22}$ he presents most of the work of the Warren Court as exemplifying his approach to constitutional interpretation, ${ }^{23}$ which he acknowledges was pre-figured by Justice Stone's Carolene Products footnote, ${ }^{24}$ and he enlists the tail end of John Marshall's opinion in McCulloch v. Maryland ${ }^{25}$ to establish the venerable roots of a representation- (or in this instance, virtual representation-) focused constitutionalism. ${ }^{26}$

But if the point of all of these citations is to establish democracy as the dominant or main theme of American constitutionalism, the effort is in vain. At least since Calder v. Bull, ${ }^{27}$ natural law (or fundamental values) theories of constitutional interpretation have vied for supremacy (or at least equal legitimacy) with theories like Ely's (and others, such as originalism). There are, of course, valid criticisms of natural law theories, and Ely makes many of them. To say that an approach or a line of decisions is wrong, however, is not to say that it does not exist or is marginal. Yet if the point of Ely's citations of Madison, the Warren Court, and John Marshall is to show that they set out the overriding themes of constitutional law, then the relevant question is

\footnotetext{
${ }^{21}$ For examples of such pluralist or "eclectic" approaches to constitutional interpretation, see, e.g., Phillip Bobbitt, Constitutional Interpretation 11-22 (1991); Richard H. Fallon, Jr., A Constructivist Coherence Theory of Constitutional Interpretation, 100 Harv. L. Rev. 1189 (1987). For a mildly critical assessment, see Michael C. Dorf, Integrating Normative and Descriptive Constitutional Theory: The Case of Original Meaning, 85 Geo. L.J. 1765, 1788-1796 (1997) (arguing that eclectic approaches fail to integrate disparate and seemingly inconsistent theories of legitimacy).

${ }^{22}$ See Ely, supra note 1, at 80.

${ }^{23}$ See id. at 105-179.

${ }^{24}$ See United States v. Carolene Prods. Co., 304 U.S. 144, 152 n.4 (1938); Ely, supra note 1, at 75-77.

2517 U.S. 316 (1819).

${ }^{26}$ Ely, supra note 1 , at $85-86$.

${ }^{27} 3$ U.S. 386 (1798).
} 
not whether cases like Roe $v$. Wade ${ }^{28}$ are correct, but whether they have a place-rightly or wrongly - in the constitutional canon. And since the whole purpose of Democracy and Distrust seems to be to banish such cases from the canon, it is hard for Ely to deny that they currently have a place there. Simply put, it makes no sense to argue that representation reinforcement is a better approach to constitutional interpretation than fundamental values solely by pointing out that our traditions of constitutional interpretation give representation reinforcement a large role; if they also give fundamental values a substantial role, as they do, then victory for representation reinforcement does not mean defeat for fundamental values.

Accordingly, Ely probably should not be read to advance the sort of argument I have been discussing. He does not invoke doctrine and original understanding along with text and structure to show that our practices as a whole make democracy the master principle of the Constitution. Rather, as I explain in the next Part, the strategy of Democracy and Distrust is a kind of constructivism of the sort practiced by John Rawls (in political philosophy) and Ronald Dworkin (in law). Before coming to that explanation, however, I need to consider three other possible ways by which democracy could be thought to be the master principle of the Constitution.

One possibility is that majoritarian democracy simply is the best form of government on utilitarian grounds. How so? The philosophical literature of utilitarianism is haunted by "utility monsters," persons who derive so much utility from satisfying their own desires—or worse, from inflicting suffering on others - that a straightforward additive calculus would weight their preferences more highly than others. ${ }^{29}$ But in both the Benthamite and Millian traditions, the principle that each person's utility counts for equal weight is usually thought to translate neatly

\footnotetext{
${ }^{28} 410$ U.S. 113 (1973).

${ }^{29}$ See, e.g., Samuel Scheffler, What is Egalitarianism, 31(1) Phil. \& Pub. Aff. 5, 16 (2003).
} 
enough into majoritarian democracy in the political realm. ${ }^{30}$ Exactly why this is so is unclear.

Perhaps the process of gauging and then assigning voting values to individuals' varying capacities for pain and pleasure is so difficult in practice that a principle of equality is the only workable one; or perhaps Bentham's principle that "each [should] count for one and none for more than one," ${ }^{31}$ is an axiomatic side-constraint to the principle of overall utility maximization. The details of the argument need not concern us here because Ely must be estopped from invoking a comprehensive moral view like utilitarianism.

Given the skeptical tone of Democracy and Distrust, some readers may be surprised to learn that Ely himself approved of democracy on utilitarian grounds, as he explained at some length in articles written both before and after Democracy and Distrust. ${ }^{32}$ The book itself, however, makes only two passing references to utilitarianism, and then only in the endnotes. ${ }^{33}$ Ely writes there "that the appeal of democracy can best be understood in terms of its connections

\footnotetext{
${ }^{30}$ See generally Thomas P. Schofield, 'Economy as Applied to Office' and the Development of Bentham's Democratic Thought, in Bentham: Moral, Political and Legal Philosophy (Gerald J. Postema ed., 2002) (arguing that Bentham's political thought became increasingly democratic through his career, and that he ultimately became a champion for democratic reform); Jeremy Bentham, The Principles of Morals and Legislation, (J.H. Burns \& H.L.A. Hart eds., 1970); J..S. Mill, Utilitarianism, Liberty \& Representative Government 72-73 (London: J.M. Dent \& Sons, 1910). The translation is hardly perfect, however. Mill himself thought that the franchise might be distributed unequally, albeit with the gradations reflecting intelligence and education rather than capacity for utility. See John Stuart Mill, Considerations On Representative Government, in Essays on Politics and Society, 371, 475 (J.M. Robson ed. 1977) (proposing that voting power be proportional to mental capacity).

${ }^{31}$ See H.L.A. Hart, Natural Rights: Bentham and John Stuart Mill, in Essays on Bentham 79 (1982).

${ }^{32}$ See John H. Ely, Democracy and Judicial Review, 17 Stan. Law. 3, 8 (1982); John H. Ely, Constitutional Interpretivism: Its Allure and Impossibility, 53 Ind. L. J. 399, 405-08 (1978); John H. Ely, Professor Dworkin's External/Personal Preference Distinction, 1983 Duke L.J. 959, 979-80. For an excellent explanation of Ely's views on utilitarianism and democracy, see James E. Fleming, Constructing the Substantive Constitution, 72 Tex. L. Rev. 211, 227 \& n.76 (1991).
}

${ }^{33}$ See Ely, supra note 1, at 187 n.13, 237-38 n.54. 
with the philosophical tradition of utilitarianism," adding that "[s]ince nothing in the . . . analysis [in Democracy and Distrust] depends on this claim, it is omitted" from the book. ${ }^{34}$

Ely is correct that his utilitarian basis for prizing democracy is unnecessary to the book's main argument in the sense that a reader who prizes democracy on non-utilitarian grounds could nonetheless find Ely's account of constitutional interpretation appealing. But what of the reader who comes to Democracy and Distrust without a deep commitment to democracy, or perhaps with a commitment to democracy but no special reason to see democracy as an overriding principle of constitutional interpretation? Because Ely's express strategy of finding democracy in the Constitution itself — whether conceptualized narrowly as text and structure or more broadly as text, structure, original understanding, doctrine, and so forth-fails, this reader will need some reason external to the Constitution to see democracy as an overriding constitutional principle.

Could the correctness of utilitarianism be such a reason? It could not, because even if utilitarianism is correct, it is hardly uncontroversially so. Ely's whole brief against the fundamental values approach to constitutional interpretation is that fundamental values are in the eye of the beholder. Complex and controversial philosophies cannot, he complains, be the basis for judicial review. Ridiculing the idea, he writes: "We like Rawls, you like Nozick. We win, 63. Statute invalidated." 35 It hardly needs saying that "I like Bentham" is equally ridiculous. Accordingly, although Ely believed in democracy on utilitarian grounds, he properly excluded those grounds from Democracy and Distrust, not so much because they are unnecessary as because they are inconsistent with the book's basic argument.

I have already adverted to the penultimate reason that Democracy and Distrust seems to offer for treating democracy as the master principle of constitutional law: In the early pages of

\footnotetext{
${ }^{34}$ Id. at 187 n. 13 .

${ }^{35}$ Id. at 58 (internal quotation marks omitted).
} 
Democracy and Distrust, and repeatedly throughout the book, Ely asserts that "We the People" value democracy quite highly, and have done so since the Founding. To the extent that these statements are true, they provide a reason why most readers of Democracy and Distrust will come to the book predisposed to agree with an argument that highly values democracy. But if these statements are meant to provide normative grounds for why an agnostic reader should treat democracy as the central principle of constitutional democracy, the argument appears to be circular. ${ }^{36}$ It amounts to saying that we should do what the majority says because the majority believes we should do what the majority says. Well, we might equally say—in a military dictatorship — that we should do what the dictator says because the dictator believes we should do what he says. Of course, widespread belief in a proposition can, under certain circumstances, count as a reason for belief in the truth of that proposition, but it cannot (non-circularly) count as a reason for belief in the truth of the proposition that widespread belief is a valid criterion of truth.

Finally, one might think that skepticism provides a basis for believing in democracy. As his belief in utilitarianism indicates, Ely was not a skeptic in the sense of a person who denied the existence of moral truths. But Democracy and Distrust might be called epistemically skeptical: Given that "We the People" disagree both about the content of moral truth and the best means for arriving at moral truth, the book seems to say, we may as well just vote and let the majority decide.

But this argument is no less conclusory than the prior one. Why is majority vote the default decision procedure? We can stipulate that, ceteris paribus, it is better for the majority

\footnotetext{
${ }^{36}$ I call this a mere appearance of circularity because, as I explain in the next Part, Ely is best read as providing a different sort of argument in which the Popular will remains relevant but not simply on selfreferential majoritarian grounds. See infra, TAN 42.
} 
than the minority to rule. But what if the minority has some special quality that the majority lacks? Why isn't the default procedure rule by the best educated, or the wisest, or the most powerful, or the least powerful, etc.? There may well be good reasons to prefer majority rule to any other decision procedure, but our mere inability to agree on important matters is not, by itself, one of them.

Thus, although most readers bring a strong preference for majoritarian democracy to Democracy and Distrust, neither the explicit nor implicit arguments offered in the book provide grounds for agnostic or skeptical readers to treat majoritarian democracy as the master principle of constitutional interpretation.

\section{Constructivism in Ely, Dworkin and Rawls}

All is not lost, however, because most of the grounds I have just rejected for treating majoritarian democracy as the Constitution's master principle turn out to support Ely's argument if we understand that argument somewhat differently from its usual formulation. As I indicated at the beginning of the prior Part, Ely appears to be making a two-step argument: (1) a positive claim about the democratic nature of the Constitution; and (2) an inference from the positive claim that results in a prescriptive claim about constitutional interpretation, namely, that the Constitution's open-ended provisions ought to be interpreted in a way that reinforces democracy. In this Part, I want to suggest a different account of Ely's project. I suggest that Democracy and Distrust actually offers what Ronald Dworkin has called an interpretive account—one that combines descriptive and prescriptive elements, but not in the two-step fashion that appears on the face of the book. ${ }^{37}$

\footnotetext{
${ }^{37}$ For an insightful understanding of Ely's work that proceeds in a similar vein, albeit in a very different ultimate direction, see Fleming, supra note 32, at 220 - 240.
} 
I can best explain what I have in mind by an interpretive account by reference to interpretation outside of law. Suppose you like baroque music best of all; if asked to explain why you prefer Bach and Vivaldi to Brahms and Mahler, you might give some account about the almost mathematical precision of the former, or you might just shrug your shoulders and say there's no accounting for taste, but in any event, you are certain of the fact of your preference. Now suppose further that you are asked to conduct a performance of a Mahler symphony. Notwithstanding your preference for baroque over romantic music, you might nonetheless concede that the best interpretation of the music is in the romantic style. In saying so, you do not deny that it would be possible to perform the symphony in a different style, perhaps transcribed for a harpsichord; you might even say that to your own ear the Mahler symphony would sound better if re-scored in the baroque style, or that someone else with very different tastes might think it would sound best of all if performed as hip-hop. But you acknowledge that the best interpretation of the Mahler symphony, as a Mahler symphony, is in the original romantic style. To borrow Dworkin's language, you would say that the romantic style best "fits" the symphony. ${ }^{38}$

Likewise with the Constitution. You might think that the best form of government is a benevolent dictatorship, but upon reading the Constitution's text and familiarizing yourself with the cultural understandings that have grown up around the Constitution, you recognize that the document is best interpreted as the charter for a democracy. In saying so, you do not deny that it would be possible to read the Constitution as making the President a virtual dictator, at least in

\footnotetext{
${ }^{38}$ This is not much of a stretch. Dworkin develops his account of interpretation for practices other than law. See Ronald Dworkin, Law's Empire 46-49, 68-73 (1986) (describing interpretation of the social practice of courtesy).
} 
certain spheres (as President Bush's Office of Legal Counsel apparently reads it), ${ }^{39}$ or that someone else with very different views about political theory might prefer to read provisions like the Equal Protection Clause as guaranteeing a right to minimum welfare. ${ }^{40}$ But you acknowledge that the best interpretation of the Constitution, as a constitution that plays the role in our society that the actual Constitution plays, is as a charter of democracy.

If you take this interpretive attitude, then the fact of popular commitment to democracy can make a difference to whether democracy should be seen as a master principle to guide resolution of particular ambiguities. To show why, let me press the music analogy a bit further. What do we mean when we say that a romantic performance of a Mahler symphony best "fits" the symphony? We might mean that this is what Mahler intended. But this kind of "originalism" in musical interpretation is highly controversial. To be sure, over the last generation, there has been keen interest in performances on "period instruments," but even the most avid (musical) originalists do not insist on performance spaces with poor acoustics or other limitations from the original period. More to the point, much of what we mean by characterizing a Mahler symphony as romantic rather than baroque (or classical or hip-hop) is that the typical audience for Mahler symphonies expects them to be performed in the romantic style. Thus when you, my hypothetical baroque music aficionado, say that even you concede that the romantic

\footnotetext{
${ }^{39}$ See Memorandum from Jay S. Bybee to the Honorable Alberto R. Gonzales, Counsel to the President, Standards of Conduct for Interrogation under 18 U.S.C. $\S \S 2340-2340$ A, 31-39 (Aug. 1, 2002) available at http://www.washingtonpost.com/wp-dyn/articles/A38894-2004Jun13.html [hereinafter Bybee Memo] (stating that a federal statute imposing criminal penalties for acts of torture committed by persons acting under color of law is unconstitutional to the extent that it interferes with the President's power as Commander-in-Chief to direct interrogations of enemy combatants in wartime).

${ }^{40}$ See generally Frank I. Michelman, Foreword: On Protecting The Poor Through The Fourteenth Amendment, 83 Harv. L. Rev. 7, 9 (1969) (proposing that minimum welfare, rather than equality of resources, explains the Warren Court rulings invalidating state failures to waive fees or provide free services for criminal defendants and others); Edward B. Foley, Interpretation and Philosophy: Dworkin's Constitution, 14 Constitutional Commentary 151 (1997) (advocating judicial recognition of a fundamental right to a living wage and criticizing Dworkin's apparently textualist reading of the Constitution).
} 
style better fits Mahler than the baroque style, you do not deny that you would be happier to live in a world in which most people's expectations had changed, so that people preferred, and came to expect, Mahler symphonies performed on harpsichords. Alas, however, you don't live in that world, and so you concede that in light of our existing social practices, the romantic style in fact best fits Mahler's music.

Again, likewise with the Constitution. You, my hypothetical believer in benevolent dictatorship, can imagine the day when permanent war has led Congress to suspend the Writ of Habeas Corpus indefinitely, when the notion of a theater of war has been so far expanded by the fact of stateless terrorists that it applies everywhere, ${ }^{41}$ and where the conception of inherent Presidential authority as Commander in Chief has been nearly universally accepted. In such an imaginary world, it would be quite consistent with popular understandings of the role the Constitution plays in our society for the President to be a benevolent dictator, albeit an elected one. But, you ruefully acknowledge, we don't (yet) live in such a world, and so in the actual here and now, you accept that the Constitution is best interpreted as a fundamentally democratic charter that limits Presidential power.

I contend that Democracy and Distrust is best read—dare I say best "interpreted"?—as making an argument of this form. Yes, originalist (what Ely calls "clause-bound interpretivist") and fundamental values approaches to constitutional interpretation cannot be logically ruled out. But to read the Constitution in these ways would be out of step with both its text- the musical notes, if you will—and the cultural understandings that surround the Constitution. So even if you're the kind of person who would rather downplay the democratic character of the

\footnotetext{
${ }^{41}$ But cf. the Steel Seizure Case, 343 U.S. 579, 587-589 (1952) (recognizing that the concept of "theater" of war is an "expanding" one but establishing that at least absent express Congressional authorization, it does not authorize the Presidential seizure of private property simply to prevent a labor dispute).
} 
Constitution - akin to the kind of person who wants to hear Mahler performed on a harpsichord or by a hip-hop artist—you'll have to acknowledge that your interpretation doesn't fit with the Constitution as generally known and understood.

Thus, we see a non-circular role in Ely's argument for the widespread belief that American government is and should be democratic. It is non-circular despite including a role for popular understandings because those understandings must be blended in some way with text, doctrine, and the other matters relevant to constitutional interpretation. Even if a clear majority of the public thought that the Constitution were best read as a charter of, let us say, socialism, ${ }^{42}$ that would not by itself make this the best reading of the document, given its text, history, and the fact (if it were a fact) that informed opinion overwhelmingly rejected that reading. Thus, we are not building into the definition of interpretation any assumption that whatever the majority says goes. And we can also see that the interpretive version of the argument is not circularly rigged simply by noting that Ely's account does not win by a slam dunk over rivals like originalism or Dworkin's fundamental values approach. The fact that the People value democracy is a datum that each of these approaches must take into account, but the further fact that one can take account of popular faith in democracy without automatically landing on representation reinforcement as the best interpretation shows that representation reinforcement makes non-circular use of the value the People place on democracy.

Yet understanding Ely's argument in the interpretivist fashion that I have described leaves him open to a number of other objections. The first that I shall consider goes as follows:

\footnotetext{
${ }^{42}$ Cf. Americans' Knowledge of the U.S. Constitution (Columbia Law Survey 2002), available at $<\mathrm{http}$ ://www2.law.columbia.edu/news/surveys/survey_constitution/Survey.pdf $>$ (finding, in a random telephone survey of approximately 1,000 Americans, that thirty-five percent answered "yes" and thirtyfour percent responded "don't know," to the question whether the U.S. Constitution contains the statement "[f]rom each according to his ability, to each according to his needs.")
} 
If the Constitution and its surrounding cultural understandings were uncontroversially classifiable as democratic in the way that Mahler is uncontroversially classifiable as a romantic composer, then Ely's interpretive argument might work. But in fact, the Constitution is more like Beethoven, whose music sits on the borderline of the classical and romantic styles, sometimes exhibiting the characteristics of each in different movements of the very same work, as in his Ninth Symphony. So too, with the Constitution, as I noted in the previous Part. As Ely observes, most of the words of the Constitution deal with structures of governance, but as Dworkin observes, the best-known parts, like the Bill of Rights and Fourteenth Amendment, at least provide support for a fundamental values approach.

Furthermore, the same problem arises at the level of popular understandings. Yes, Ely is right that the People expect the government to be democratic to be legitimate, but they also expect the courts to enforce substantive as well as procedural limits on majority rule. Particular decisions may draw fire, and when they draw sufficient fire, popular sentiment may for a time turn against the institution of judicial review, ${ }^{43}$ but judicial review to enforce substantive limits on government has been part of the American system of constitutional government for so long that by now it almost certainly counts as part of what the People mean by democracy. To borrow Dworkin's somewhat question-begging language, there is a good case to be made for the proposition that the People hold a "constitutional" as opposed to a "majoritarian" conception of

\footnotetext{
${ }^{43}$ See, e,g, Barry S. Friedman, The History of the Countermajoritarian Difficulty, Part I: The Road to Judicial Supremacy, 73 N.Y.U. L. Rev. 333, 415-418 (1998) (chronicling the "firestorm of criticism" and "loss of confidence of the people" in the wake of the Dred Scott decision); Barry S. Friedman, The History of the Countermajoritarian Difficulty, Part II: Reconstruction's Political Court, 91 Geo. L.J. 1, 3-4 (2002) (asserting that politics can both "threaten" and "preserve" judicial independence); Barry S. Friedman, The History of the Countermajoritarian Difficulty, Part III: The Lesson of Lochner, 76 N,Y.U. L. Rev. 1383, 1387 (2001) (noting that "if those familiar with the Court's decisions do not believe those decisions to be socially correct, the work of judges will be seen as illegitimate.).
} 
the concept of democracy. ${ }^{44}$ Or perhaps public attitudes towards the Constitution are simply a confused jumble, amorphously valuing both "democracy" and "rights" without a clear conception of either concept, so that a very broad range of practices could be validated by showing their acceptability to the People.

At this point we may be tempted to say that the debate between Ely and Dworkin must come to a standstill. Neither can show that his approach-representation reinforcement versus fundamental values - finds definitive support in the text, structure or cultural understandings of the Constitution, and so the argument ends in a draw. If so, that is bad news for Ely, for Democracy and Distrust aims not only to establish the bona fides of representation reinforcement but to banish fundamental values as well. Representation reinforcement is offered as the method by which the Constitution's open-ended provisions should be interpreted.

But Ely can turn to Dworkin's notion of interpretation once again. For Dworkin, rival interpretations should be measured along two dimensions: how well they fit the interpreted practice and how well they justify that practice. ${ }^{45}$ Ely could grant that a reasonable case could be made for either a representation reinforcing approach or a fundamental values approach on grounds of fit, but go on to argue that representation reinforcement does a better job of justifying the practice of judicial review, and that therefore, as the law "works itself pure," 46 fundamental values decisions will disappear, replaced by decisions rooted in representation reinforcement.

And in fact, that is more or less the strategy of Democracy and Distrust. Following Hart and Sacks, Wechsler, and the other constitutional proceduralists of the generation that preceded

\footnotetext{
${ }^{44}$ Dworkin, supra, note 2, at 15-19.

45 See id. at 90 ("General theories of law . . try to show legal practice as a whole in its best light, to achieve equilibrium between legal practice as they find it and the best justification of that practice.").

${ }^{46}$ Dworkin, supra, note 38 at $400-413$.
} 
him, Ely argues on institutional competence grounds that the courts ought not be in the business of discovering fundamental values. ${ }^{47}$ Courts are competent to police the ground rules of democracy, the argument goes, but (except where the rights of minorities are overridden), they should generally leave substantive policy judgments to elected officials. It is a little like saying that as between interpreting the music of some transitional composer-say C.P.E. Bach—in the baroque versus the classical style, we should choose the baroque style if the only instrument we have available is a harpsichord. ${ }^{48}$

Ely need not establish that majoritarian democracy is the only plausible master principle with which to make sense of the Constitution and our constitutional practices. He can acknowledge (as he does in fact acknowledge) ${ }^{49}$ that fundamental values provide a plausible rival principle. Nor need Ely demonstrate as a matter of first-order moral philosophy that democracy is the best form of government on utilitarian (or other) grounds. He need only show that the principle of representation reinforcement is better suited for use by judges than a

${ }^{47}$ See Herbert Wechsler, Toward Neutral Principles of Constitutional Law, 73 Harv. L. Rev. 1, 19 (1959) (arguing that courts are obliged to be "entirely principled," and must base their decisions on neutral concerns that "transcend any immediate result that is involved"); Henry M. Hart Jr. \& Albert M. Sacks, The Legal Process: Basic Problems in the Making and Application of Law (1958) (envisioning judges as best suited to making decisions about which other institutions to grant deference). For a discussion of Hart, Sacks, the Legal Process School, and the implications of their thinking on the questions of fundamental values jurisprudence faced by the Warren Court, see Neil Duxbury, Faith in Reason: The Process Tradition in American Jurisprudence 15 Cardozo L. Rev. 601, 634 (discussing a series of articles written by Frankfurter and Hart in which they warned against "undue suction into the avoidable polemic of politics"') (quoting Felix Frankfurter \& Henry M. Hart, Jr., The Business of the Supreme Court at October Term, 1934, 49 Harv. L. Rev. 68, 90-91 (1935)); William N. Eskridge, Jr. and Philip P. Frickey, Commentary: The Making of the Legal Process, 107 Harv. L. Rev. 2031, 2049—51 (1994) (arguing that the Legal Process materials of Hart and Sacks could not, without substantial modification, make sense of the civil rights and successor movements that found a sympathetic ear in the Warren Court).

${ }^{48}$ I recognize that this is not a perfect analogy, because the music of C.P.E. Bach could be classified as neither baroque nor classical but as rococo. Because I am more interested here in constitutional interpretation than in musical interpretation, I beg the reader's indulgence in the admittedly unrealistic assumption that performers must choose between the baroque and classical styles.

${ }^{49}$ See Ely, supra note 1 , at $11-14$. 
principle of fundamental values, and thus that, all things considered, it provides a better justification for the practice of judicial review than having judges discover fundamental values (and other alternatives).

Accordingly, to the extent that one finds Ely's argument about relative institutional competence persuasive, understanding Democracy and Distrust as interpretive in Dworkin's sense enables Ely to escape the objection that he has no adequate basis for selecting democracy as his master principle without requiring him to invoke the sort of controversial moral principles (such as utilitarianism) that the overall thrust of his argument rules out of bounds. That does not mean that Ely's argument is necessarily persuasive, of course. One might still think, with Tribe, Dworkin and others, that the courts are competent to make principled judgments about substantive values no less than procedural ones; or one might think—as Felix Frankfurter thought and as some commentators suggested in the wake of Bush v. Gore ${ }^{50}$-that institutional considerations render the Court incompetent to make controversial judgments with respect to the mechanics of democracy in the same way that courts are incompetent to make other, nominally more substantive controversial judgments. ${ }^{51}$ These are the mirroring criticisms to which I

\footnotetext{
50 531 U.S. 98 (2000).

${ }^{51}$ See Jeff Polet, The Imperiousness of Bush v. Gore, in The U.S. Supreme Court and the Electoral Process 272-79 (David K. Ryden ed., 2d ed. 2002); The Supreme Court as Architect of Election Law: Summing Up, Looking Ahead in The U.S. Supreme Court and the Electoral Process 306 (David K. Ryden ed., 2d ed. 2002) (evaluating the Court's record in recent election law cases and stating that the Court manifests "a disturbing proclivity for easy conclusion unaccompanied by explanation, elaboration, or elucidation" and that "one need not disagree with the outcome to be troubled by the Court's failure or refusal to at least acknowledge the larger issue involved").

For two reasons, the claim that judges will be no less result-oriented in cases involving the electoral process than in cases involving directly substantive values is hardly devastating to Ely's argument. First, the claim may be false; judicial philosophy does not perfectly track partisan politics. For example, the Court's conservatives have been most aggressive in seeking to invalidate so-called racial gerrymanders, see, e.g., Miller v. Johnson, 515 U.S. 100 (1995), even though such gerrymanders, by "packing" overwhelmingly Democratic African-Americans into a small number of districts, tend to ensure that the remaining, largely white districts, are safe for Republicans. See Michael C. Dorf, The
} 
adverted in the Introduction, and of course understanding Ely's claims as interpretive will not simply make them go away. What my "interpretive interpretation" is meant to suggest is that, despite the argument I put forth in Part I, Democracy and Distrust does offer considerable support for treating democracy as the master principle of constitutional interpretation.

To be sure, there remain objections to interpretivism more generally. First, one might object that there is no need whatsoever for a master principle or guiding philosophy for constitutional interpretation. Various forms of pragmatism as muddling through ${ }^{52}$ - which I would distinguish from a different sort of pragmatism that I discuss in response to the next objection I'll consider - assert that abstract principles like fundamental values or representation reinforcement are at best unnecessary and at worst harmful to judges who must hammer out collective decisions dealing with the messy problems of real life. Holmes' aphorism that "general propositions do not decide concrete cases" $" 53$ pithily sums up this attitude, which has been lately revived in the work of Daniel Farber and Suzanna Sherry, Richard Posner, and Cass Sunstein. ${ }^{54}$

2000 Presidential Election: Archetype or Exception, 99 Mich. L. Rev. 1279, 1291 (2001) (reviewing Issacharoff et al, When Elections Go Bad (2001)).

Second, even if the claim is true, Democracy and Distrust makes a point about relative, not absolute institutional competence. We think it is perfectly appropriate for legislatures to act in a "resultoriented" manner in fashioning public policy in general, such behavior strikes us as illicit self-dealing when it comes to refereeing elections. Although judges certainly are not immune from (perhaps subconscious) partisan impulses, they are, on the whole, less likely to succumb to these impulses, as was evident even in the 2000 Presidential election. See id. at 1292-95 (arguing that on the whole, courts performed in a less partisan manner than elected officials in the controversy following the 2000 Presidential election).

${ }^{52}$ See Charles E. Lindblom, The Science of Muddling Through, 19 Pub. Admin. Rev. 79, 80-88 (1959) (defending a method of problem solving that asks incremental questions rather than measuring various approaches by reference to some ideal solution).

${ }^{53}$ Lochner v. New York, 198 U.S. 45, 76 (1905) (Holmes, J., dissenting).

${ }^{54}$ See Daniel A. Farber \& Suzanna Sherry, Desperately Seeking Certainty: The Misguided Quest for Constitutional Foundations 3 (2002) (opposing "grand theory" and advocating a version of pragmatism that looks to multiple sources of meaning as guided by practical common sense); Richard A. Posner, Law, 
Although there is much good sense in their prescriptions, the muddlers' fundamental objection is mistaken. The difficulty stems from what Dworkin calls the phenomenon of "justificatory ascent." ${ }^{55}$ In our legal culture, courts cannot simply decide cases by saying "plaintiff loses." They must provide reasons for their decisions, and reasons are typically more abstract than the decisions they purport to justify ${ }^{56}$ For Dworkin, the requirement that the law exhibit integrity requires that reasons be reconciled with one another in what becomes a grand synthesis. ${ }^{57}$ To be sure, one need not go so far in the direction of abstraction as Dworkin goes. Courts can, to use Sunstein's terminology, provide "shallow" or "narrow" reasons for a decision. ${ }^{58}$ But they must still have a meta-reason for stopping at the shallow or narrow reason. Sunstein provides a persuasive one: sometimes it will be impossible for a majority of Justices to agree on the rationale for a decision though they agree on the result, and for reasons of public acceptability, it is important that the Court speak with one voice; in such circumstances, it may well be perfectly appropriate for the Court to provide an "incompletely theorized" account of its decision. But if so, then the justification for failing to provide a more completely theorized explanation is itself a theory of interpretation in the same way that Dworkin's principle of integrity or Ely's principle of representation reinforcement is. Granted, one will not usually find

Pragmatism and Democracy 59 (2003) (describing legal pragmatism as a form of instrumentalism); Cass R. Sunstein, One Case at a Time: Judicial Minimalism on the Supreme Court (1999) (generally defending the Supreme Court's failure to provide a theoretically satisfying account of its interpretive practices). Posner comes the closest of these scholars to developing an argument for judicial pragmatism that links up with the main themes of the leading pragmatist philosophers: John Dewey, William James, and Charles Sanders Peirce. See Richard A. Posner, The Problematics of Moral and Legal Theory 99, 22765 (1999).

${ }^{55}$ Ronald Dworkin, In Praise of Theory, 29 Ariz. St. L.J. 353, 356-57 (1997).

${ }^{56}$ See Frederick Schauer, Playing by the Rules (1993) 17-37.

${ }^{57}$ Dworkin, supra note 2, at 225-38 (describing interpretive project of "law as integrity" and comparing the task of the judge to that of an author attempting to contribute a chapter to a "chain novel").

${ }^{58}$ Cass R. Sunstein, Foreword: Leaving Things Undecided, 110 Harv. L. Rev, 4, 15-21 (1996). 
in the decisions themselves a statement to the effect that "we can't agree on a deep principle so we're providing a shallow one," but then neither will one find much in the U.S. Reports espousing other theories. The whole point of a book like Democracy and Distrust is to provide a justificatory account of what the Court has really been up to - an interpretation— just as the point of the muddlers' books is to provide a (very different) justificatory account for what they think the Court has really been up to. Whose explanation better fits and justifies the Court's practices is not really the point (right now). The point is that "muddle through" is no less a descriptive and prescriptive, and thus interpretive, account of judicial review than is "reinforce representation" or "seek integrity," or "honor the original understanding."

Nonetheless, understanding Ely to be making an interpretive argument still leaves him open to a second, and more troubling general criticism of interpretivism. Minor differences notwithstanding, interpretivism is a form of constructivism or coherentism of the sort most famously advanced by Rawls. ${ }^{59}$ The measure of a constructivist doctrine or account of some practice — such as constitutional democracy or political justice —is

how well the view as a whole meshes with and articulates our more firm considered convictions, at all levels of generality, after due examination, once all adjustments and revisions that seem compelling have been made. A doctrine that meets this criterion is the doctrine that, so far as we can now ascertain, is the most reasonable for us. ${ }^{60}$

\footnotetext{
${ }^{59}$ For a discussion of the similarities and differences between reflective equilibrium in the work of Rawls and the principle of integrity in the work of Dworkin, see Fleming, supra, note 32, at 227 (also fitting Ely into this pattern).

${ }^{60}$ John Rawls, Kantian Constructivism in Moral Theory, 77 J. Phil. 515, 534 (1980) (defining "reflective equilibrium"). Rawls sets out his full account of reflective equilibrium in Rawls, supra note 10, at 48-51.
} 
In Democracy and Distrust, the relevant "we" is We the American People, the doctrine is "representation reinforcement," and the practice is judicial review.

The difficulty facing Ely the coherentist is the same as that facing all coherentistsnamely, that a doctrine that is reasonable to us or that meshes with our firm considered convictions may nonetheless be wrong or unjust. De jure racial segregation and exclusion of women from most employment opportunities fit well with the considered convictions of the American Republic circa 1900, but few would defend either practice today. Given the possibility of "bad coherence,"

I call this a "troubling" objection because most people, including me, don't like to think of themselves as moral relativists. When we say that slavery is wrong we think we mean that it is really wrong, not simply that we don't like it (a philosophical view called emotivism) ${ }^{62}$ or that we as a society firmly believe today that slavery is wrong, although people in other times and places thought slavery was morally acceptable and our own society may come to think the same thing again in the future.

Some of us might be willing to root our objections to slavery and other practices we condemn as immoral in religious faith; it is not simply our own subjective convictions but God's Law that makes slavery immoral; and some might even go further to say that this sort of argument from authority is the only way that one can establish moral truth, as opposed to refining our own fallible and subjective intuitions. ${ }^{63}$ But even if most religious traditions agree

\footnotetext{
${ }^{61}$ See Radin, supra note 11, at 1705-11.

${ }^{62}$ Emotivism is a meta-ethical theory which holds that moral statements convey no cognitive meaning and have no truth value; to say that "x is wrong" is simply to say "boo" for x. See, e.g., A.J. Ayer, Language, Truth, and Logic (1936); Charles Stevenson in, Charles Stevenson, Ethics and Language (1945).

${ }^{63} \mathrm{Cf}$. MacIntyre, supra note 11, at 36-61 (chronicling what the author deems the failure of the enlightenment project of wresting moral argumentation from religious justifications).
} 
about the wrongfulness of slavery, ${ }^{64}$ the diversity of religious beliefs about other matters (such as abortion, the death penalty, homosexuality, and the proper role of women) in a society like the modern United States, makes religion an inappropriate basis for collective moral reasoning. Accordingly, Rawls contends that arguments about political justice must be rooted in a form of "public reason" that holds religious convictions at arm's length. ${ }^{65}$

If coherentists cannot or will not invoke religious authority as grounds for the "reality" of their firm normative convictions, are our moral sentiments "unreal?" Are they simply hazy and often conflicting generalizations of crude behavioral rules that may have conferred some evolutionary advantage on our hunter-gatherer ancestors but have no force today beyond what they may contribute to some arbitrarily chosen system of value $?^{66}$ The perhaps maddeningly unhelpful answer of a pragmatist to such a question is simply to unask it. As William James asks, "what difference would it practically make" ${ }^{67}$ if we were to add to our moral sentiments, properly sifted at all levels of generality to reflect our considered convictions, the adjective

\footnotetext{
${ }^{64}$ Whatever the world's leading religions currently say about slavery, the original sacred texts of Judaism, Christianity, and Islam all condone slavery, see, e.g., Book of Leviticus 25:44-46 (permitting the Israelites to enslave people of other nationalities); Book of Matthew 10:24 (attributing to Jesus the statement that "[t]he disciple is not above his master, nor the servant above his lord."); Koran, 33:50 ("Prophet, We have made lawful to you the wives to whom you have granted dowries and the slave girls whom God has given you as booty."), as does a sacred text of Hinduism, see, e.g., Rig Veda, Book 8, Hymn 19, verse 36, which also establishes a caste system still in effect today. Admittedly, Buddhism does criticize both slavery specifically and class-based distinctions more generally, see Sutta-Nip. 136, ("Not by birth is one an outcast. /Not by birth is one a noble./ But by deeds is one an outcast. /And by deeds is one a noble."), but it hardly requires stating that Buddhists have never comprised more than a tiny fraction of the American population.

${ }^{65}$ See Rawls, supra note 12 at 224-25 ("in discussing constitutional essentials and matters of basic justice we are not to appeal to comprehensive religious and philosophical doctrines").

${ }^{66}$ See Richard Posner, The Problematics of Moral and Legal Theory, 111 Harv. L. Rev. 1637, 1659—64 (1998) (arguing that our moral sentiments are a contingent accident of evolutionary pressures). For an ambitious utilitarian account of seemingly deontological moral sentiments, see generally Louis Kaplow \& Steven Shavell, Fairness Versus Welfare, 114 Harv. L. Rev. 961, 966 (2001) (arguing that "the assessment of legal policies should depend exclusively on their effects on individuals' welfare.).

${ }^{67}$ William James, Pragmatism 23 (1991) (orig. pub. 1907).
} 
"real?" If we do not think that the reality of normative propositions consists in their correspondence to Divine will or some such supernatural relation, then what could it possibly mean for us to say that normative propositions have a "reality" apart from our willing them as considered judgments in reflective equilibrium? Dworkin nicely puts the point by ridiculing the notion that the truth of moral propositions might be established by the alignment of a "moral field" of tiny particles he playfully dubs "morons." 68

"Hold it, Dorf," ${ }^{69}$ I imagine the philosophers in the audience exclaiming. "Dworkin was making the exact opposite point as a criticism of Richard Rorty and other pragmatists. He's even called pragmatism 'an empty theory. ${ }^{, 70}$ You can't lump Dworkin with the pragmatists (you ignoramus)."

Well, all I can say is "hold it yourselves, philosophers." Maybe I'm missing something here, but to this simple country (okay, city) lawyer, it looks like Dworkin is agreeing with Rorty, who ridicules the notion that normative propositions might exist in what he calls "Reality as It Is In Itself., ${ }^{, 11}$ Dworkin's morons comprise Rorty's Reality as It Is In Itself, and both Dworkin and Rorty agree that it makes no sense to talk about either, because an additional "ultimate" level for our considered convictions makes no practical difference to anything, and thus can be discarded on Jamesian grounds.

The actual difference between Dworkin and Rorty (as well as some other pragmatists) concerns physical reality rather than the domain of value. Dworkin appears to hold the conventional view of the physical world as simply "out there," independent of our observations

\footnotetext{
${ }^{68}$ Ronald Dworkin, Objectivity and Truth: You Better Believe It, 25(2) Phil \& Pub. Aff. 87, 104 (1996).

${ }^{69}$ Cf. Ely, supra note 1at 163 ("Hold it, Lester").

${ }^{70}$ Ronald Dworkin, Darwin's New Bulldog, 111 Harv. L. Rev. 1718, 1736 (1998).

${ }^{71}$ Richard Rorty, Does Academic Freedom Have Philosophical Presuppositions?, in Louis Menand, ed, The Future of Academic Freedom 21, 30 (Chicago 1996). See Dworkin, supra note 68, at 95.
} 
of it. He invokes his whimsical morons to show that, by contrast with propositions about the physical world, the truth of moral propositions does not consist in their correspondence with external reality. ${ }^{72}$ For Rorty, by contrast, physical objects have no greater claim to exist in Reality as It Is In Itself than normative propositions do. ${ }^{73}$ His work aims to dislodge a view of knowledge in which our mental images mirror the external world. ${ }^{74}$ This is undoubtedly an interesting metaphysical debate, but it need not concern us here. With respect to our concern, normative propositions, we are justified in treating Dworkin's coherentism as pragmatic.

And likewise for Rawls. The task of Political Liberalism, he says at the very outset, is to answer the question: "how is it possible for there to exist over time a just and stable society of free and equal citizens, who remain profoundly divided by reasonable religious, philosophical, and moral doctrines?"75 That might seem like an empirical question. By pointing to various actual liberal societies that are (more or less) just and stable, one could show the possibility of their persistence. But even apart from the fact that no human society appears ever to have adopted all of the principles Rawls espouses, this is not the way that he means the question. He means something more like: "if it were possible for a just and stable society of free and equal citizens, who remain profoundly divided by reasonable religious, philosophical, and moral doctrines, to persist over time, what characteristics would that society have?" That this is his question is evident from the methodology of both Political Liberalism and A Theory of Justice. Both begin with a set of intuitions that, Rawls claims, are widely shared by members of actual liberal democracies, and then offer coherentist accounts of these intuitions.

\footnotetext{
${ }^{72}$ See Dworkin, supra note 68, at 103-05

${ }^{73}$ Rorty's dismissal of "Reality as It Is In Itself" occurs in the context of a discussion of the reality of mountains. See Rorty, supra note 71, at 30.

${ }^{74}$ See Richard Rorty, Philosophy and the Mirror of Nature (1981).

${ }^{75}$ See Rawls, supra note 12, at 4.
} 
The contrast between A Theory of Justice and Political Liberalism highlights the pragmatic nature of the account of value offered in both. Rawls explains in the Introduction to the latter that the differences between the two works stem from his realization that "[a] modern democratic society is characterized by ... a pluralism of reasonable ... doctrines" regarding the basic institutional arrangements of political life." ${ }^{76}$ The fact of pluralism is, of course, contingent. We might have found ourselves in a society in which all reasonable citizens accepted Rawls' notion of justice as fairness; or we might have found ourselves in a society in which nearly all citizens (whether reasonable or not) accepted the authority of a ruler who claimed legitimacy by Divine Right or through force of arms. Although Rawls clearly prefers to live in the sort of society that his books elaborate,${ }^{77}$ the burden he sets for himself is not to show, as a matter of first principle, that a politically liberal society is the best sort of society in which human beings can live. Instead, he aims to work out the institutional entailments of the shared premises of citizens in the sorts of liberal societies that actually exist. Thus, Rawls' coherentism works in true pragmatist fashion. It makes the only sort of truth claim that the pragmatist allows can be made for normative propositions, and it makes only that sort of truth claim. ${ }^{78}$

\footnotetext{
${ }^{76}$ See id. at xviii.

${ }^{77}$ See id. at lxii (contrasting a politically liberal society with one run by "power and coercion alone," the dominance of which would raise Kant's question "whether it is worthwhile for human beings to live on the earth").

${ }^{78}$ I might soften this assertion in two ways. First, nothing in my argument about how best to understand Ely turns on whether Rawls is really a pragmatist of the sort I say he is. Readers who insist on reading Rawls as setting forth universal rather than contingent claims should consider my discussion of Rawls as merely an illustrative example to set the stage for my discussion of Ely. These readers should imagine that I have described the works of a hypothetical philosopher, call him "Shmawls." Second, even those readers who are generally willing to go along with my account of Rawls might be inclined to add the caveat that Rawls does build into his account what appears to be an axiomatic rather than an empirical picture of the person. See Rawls, Political supra note 12, at 18-20. I would point these readers to Rawls' statements suggesting that the conception of the person must at least be acceptable to, if not strictly derived from, the society whose basic features Rawls aims to describe, refine and justify. See, e.g., John Rawls, Kantian
} 
And what of Ely? If I am right that, in order for Democracy and Distrust to succeed, it must be understood as an interpretive account of democracy and judicial review, then it is no less nor more vulnerable to the general critique of interpretivism than rival interpretations, like those of Dworkin and Rawls. How vulnerable are such accounts? Very much so and not at all. If we long for the sort of authority that religious truth plays in many citizens' personal and social lives, then we will be sorely disappointed with a mere reflective equilibrium of our considered convictions. But if — with Rawls and Ely—we rule out religious authority as an illegitimate basis for constructing the basic political institutions of our society, we will see, as do the pragmatists, that constructivism provides us with all the normative truth we can possibly expect. That doesn't mean that Ely's account necessarily wins, but it does mean that it can vie on the merits with the alternatives.

\section{Ely's Ideal Constitution}

The previous Part argued that Ely's account of American constitutionalism—which seems designed specifically to avoid having to endorse propositions of political philosophy of the sort that Ely attributes to Rawls - ironically ends up embracing (at least implicitly) a method of argument, constructivism, that is closely associated with Rawls. But wait. There's more. Ely not only adopts a method of argument associated with Rawls; he also offers a normative vision strikingly similar in its content to that offered by Rawls. Both argue that the basic framework of government should contain largely procedural guarantees that are thinner than the substantive values individual members of the society hold.

Constructivism in Moral Theory, 77 J. Phil. 515, 518 (1980) ("In addressing the public culture of a democratic society, Kantian constructivism hopes to invoke a conception of the person implicitly affirmed in that culture, or else one that would prove acceptable to citizens once it was properly presented and explained."). 
To see the substantive similarities between Ely's vision and that of Rawls, we must see beyond the differences in the nature of their respective projects. Ely provides judges with a method for interpreting the American Constitution. Rawls was not concerned with interpreting any particular constitution, and thought that "the basic structure" of a fair and just liberal polity could be guaranteed by a wide variety of constitutional arrangements. ${ }^{79}$ But both Ely and Rawls nonetheless had views about what properly belongs in a constitution, and their views turn out to be quite similar. Seeing the similarities, as well as the differences, will enable us to see that Democracy and Distrust is more ambitious than its subtitle- "A Theory of Judicial Review"suggests. It will enable us to see that Ely actually sets forth a theory of constitutionalism writ large, and to see, finally, the substantial obstacles that Ely's theory of constitutionalism must overcome if it is to be persuasive.

What is Ely's account of constitution-writing as opposed to constitution-reading? To answer that question, we must begin by acknowledging that there is no necessary connection between a theory of interpretation for an existing constitution and a prescriptive theory for constitution-writing. Suppose, for example, that our Constitution contained an Authoritative Construction Clause that said "in construing this Constitution, the judges shall in all matters be guided by the interpretive theories of Ronald Dworkin.” Even if a judge thought Dworkin all wet, she would be obliged to apply his methods under the Authoritative Construction Clause. ${ }^{80}$

\footnotetext{
${ }^{79}$ See Rawls, supra note 12 at 415-416 (stating that "constitutional design is not a question to be settled only by a philosophical conception of democracy ... in the absence of a case by case examination," but must instead take "into account the particular political history and the democratic culture of the society in question.")

${ }^{80}$ To say that a judge would be obliged to follow the Authoritative Construction Clause and apply Dworkin's theory is not to say that every judge would in fact do so or do so honestly. A judge who thought Dworkin's theory nonsensical might, for example, treat the Authoritative Construction Clause as though it were obscured by an ink blot, and thus unenforceable. Cf. Bork, supra note 3, at 166 (proposing such treatment for the Privileges or Immunities Clause of the Fourteenth Amendment).
} 
That same judge, however, if serving as a delegate to a constitutional convention, would be free to, and likely would, advocate the elimination or substantial modification of the Authoritative Construction Clause.

Our actual Constitution, of course, contains no Authoritative Construction Clause. Even if one is inclined, as I am, to read the Ninth Amendment as ruling out some methods of constitutional interpretation with respect to questions of rights, neither that Amendment nor any other provision authoritatively rules in any method of interpretation. And in choosing a method of constitutional interpretation, judges and scholars will be influenced by considerations not unlike those involved in constitution-writing. Those who would be inclined to expressly bar capital punishment were they writing a constitution will be (at least somewhat) inclined to read the Eighth Amendment as implicitly barring capital punishment; those who would be inclined to give the central government plenary power will be inclined to read the enumerated powers of Article I and beyond broadly; and those who, in writing a constitution would be inclined to give the People's representatives wide latitude in enacting substantive policy so long as they do not erect barriers to everyone's equal participation, will be similarly inclined in reading the Constitution's open-ended language.

Accordingly, it is hardly surprising that in his brief remarks on what a constitution ought to contain, Ely espouses proceduralism. ${ }^{81}$ Indeed, he goes so far as to suggest that it is in the very nature of a constitution to create a procedural framework rather than to resolve substantive issues. "The American Constitution," Ely states, "has ... by and large remained a constitution properly so called, concerned with constitutive questions. ${ }^{182}$ He then approvingly quotes Hans

\footnotetext{
${ }^{81}$ See Ely, supra note 1, at 99-101.

${ }^{82}$ Id. at 101.
} 
Linde for the proposition that "a constitution must prescribe legitimate processes, not legitimate outcomes . ..."

Putting aside the semantic question of whether a foundational document larded up with substantive, as opposed to constitutive, provisions can properly be called a "constitution," what reasons might Ely offer for limiting his ideal constitution to procedural matters? One answer is institutional competence: If, as Ely contends, judges, as lawyers, are good at enforcing rules about fair opportunities, but are not especially qualified to answer other, more substantive questions,${ }^{84}$ then it makes sense for constitution writers to assign them the former, but not the latter sort of task.

The work of Rawls nicely makes the institutional competence point. In both $A$ Theory of Justice and Political Liberalism, Rawls distinguishes between the sorts of comprehensive (thick), typically religious or religiously inspired, moral views that people hold about all sorts of matters and the "political" (thin) conception of justice that informs social choices over the long haul about the "basic structure" of a liberal democracy. ${ }^{85}$ But even the thin basic structure is remarkably thick, in the sense that it would seem to constrain policy choices on a wide range of matters. Thus, the basic structure must be constructed so as to satisfy the Rawlsian "difference principle"-which states that inequalities in the distribution of society's resources are permissible only insofar as they serve to maximize the share available to society's least fortunate members. ${ }^{86}$ I say this feature of Rawlsian political justice makes the basic structure relatively

\footnotetext{
${ }^{83}$ Id. (quoting Hans Linde, Due Process of Lawmaking, 55 Neb. L. Rev. 197, 254 (1975)).

${ }^{84}$ See Ely, supra note 1 , at $56-60$.

${ }^{85}$ See Rawls, supra note 10, at 395-399 (discussing citizens" "thin" and "thick" conceptions of the good); Rawls, supra note 12, at 303-304 (explaining how liberalism can accommodate the plurality of comprehensive doctrines in modern society). For critical discussion, see William Powers, Jr., Construing Liberal Political Theory, 72 Tex. L. Rev. 443, 447—448 (1993).

${ }^{86}$ See Rawls, supra note 10 , at $60-83$
} 
thick because it means that matters like tax rates and social welfare spending are not left to interest group bargaining in the legislature but are in some sense fixed - if not directly by the constitution or statute then at least by a procedural mechanism that is itself regarded as part of the basic structure.

Nonetheless, Rawls does not insist that every feature of the basic structure be enshrined in a judicially enforceable constitutional provision. In particular, the difference principle, though part of the basic structure, is not, for Rawls, a "constitutional essential." 87 That means that if a liberal democracy chooses to make its constitution enforceable through judicial review, it can leave the difference principle to enforcement by some other mechanism. As Rawls explains, whether the aims of the principles covering social and economic inequalities are realized is [very] difficult to ascertain. These matters are nearly always open to wide differences of reasonable opinion; they rest on complicated inferences and intuitive judgments that require us to assess complex social and economic information about topics poorly understood. ${ }^{88}$

They are accordingly properly left out of a constitution, at least one that is enforceable through judicial review. ${ }^{89}$ And likewise for Ely as well, the enforcement mechanism of judicial review plays an important role in the decision of what should go into a constitution.

Rawls and Ely are not twins in these matters, however. Rawls does not think that all substantive values must be kept out of a constitution. For example, he thinks that a just

\footnotetext{
${ }^{87}$ Rawls, supra note 12 , at $229 \& 10$.

${ }^{88}$ Id. at 229.

${ }^{89}$ Rawls himself does not include the qualifier, arguing that it would be appropriate to omit the difference principle even from a constitution that is thoroughly non-justiciable. Frank Michelman explains this puzzle by positing that for Rawls, the question whether a principle of political justice should be included in the constitution is only partly a matter of judges' institutional competence; it is also partly a matter of the principle's "urgency in relation to liberal legitimacy." Frank I. Michelman, Justice as Fairness, Legitimacy, and the Question of Judicial Review: A Comment, 72 Fordham L. Rev. 1407, 1418 (2004).
} 
constitution should include a minimal guarantee of social welfare, even if the constitution is judicially enforceable. ${ }^{90}$

To be sure, that difference between Rawls and Ely could perhaps be explained by their different assessments of the ease with which judges can enforce a social minimum. Ely might think that the enforcement of all so-called positive rights entails the sorts of complex social and economic assessments that Rawls thinks plague enforcement of distributional (but not minimum) social and economic rights. But Ely goes considerably further still. As a putative constitution writer, he argues against inclusion of any substantive rights, negative as well as positive, those that judges could enforce relatively easily as well as those that judges would have difficulty enforcing. Accordingly, although Ely invokes judicial competence as an important reason why, in interpreting the Constitution we have, courts should opt for representation-reinforcement rather than some other, more substantive, approach, ${ }^{91}$ institutional competence concerns cannot explain Ely's hostility to all substantive constitutional guarantees.

The explanation lies, not surprisingly, in Ely's commitment to democracy and his concern about the dead hand problem. Ely thinks that except on matters of procedure as to which we need clear rules of fair play, today's majority should not be bound by yesterday's super-majority, and today's super-majority should not bind tomorrow's majority. Making the point with respect to Prohibition with characteristic pith, Ely states that the Eighteenth Amendment was repealed by the Twenty-First "because such attempts to freeze substantive values do not belong in a constitution. In 1919 temperance obviously seemed like a fundamental value; in 1933 it obviously did not." ${ }^{, 92}$

\footnotetext{
${ }^{90}$ Rawls, supra note 12 , at 230.

${ }^{91}$ See Ely, supra note 1, at 102.

${ }^{92}$ Id. at 99.
} 
Ely makes a similar and more dramatic point with respect to slavery. Slavery, he wryly observes, "must be counted [as the one] substantive value to which the original Constitution meant to extend unusual protection from the ordinary legislative process. . ."93 Ely thus associates the notion of enshrining substantive constitutional values with two constitutional failures: Prohibition and slavery.

Yet, upon reflection, the slavery example would seem to undermine rather than support Ely's case for keeping substantive values out of the Constitution. After all, the Thirteenth Amendment does not simply undo the Constitution's protection for slavery. It affirmatively prohibits slavery. As Ely notes "nonslavery is one of the few values [the Constitution] singles out for protection now. ${ }^{94}$ But if, as Ely says of Prohibition, attempts to freeze substantive values do not belong in a constitution, then he must regard the Thirteenth Amendment as a mistake. Our Reconstruction Era forebears had no business going beyond saying something like "this Constitution shall not be construed to protect or prohibit the institution of slavery."

Interestingly, Ely does not deny (although he also does not acknowledge) this rather clear implication of his argument. In light of Ely's seeming inability to defend the adoption of the Thirteenth Amendment, is his substance-free approach to constitution-writing simply wrong? Or is it the intuition that the Constitution properly prohibits slavery that is wrong?

One possibility with which Ely flirts would be to defend the Thirteenth Amendment as fitting the theme of representation reinforcement. Ely states that "[t]he Thirteenth Amendment can be forced into a 'process' mold" or justified on equality grounds, ${ }^{95}$ but the emphasis here is on "forced." Presumably, a just society would forbid slavery even if it were not racialized: The

\footnotetext{
${ }^{93}$ Id. at 93.

${ }^{94}$ Id. at 98 .

${ }^{95} \mathrm{Id}$.
} 
Thirteenth Amendment, most of us surely think, rightly prohibits slavery in satisfaction of a debt, for example. If a prohibition on slavery is an example of representation reinforcement, then almost anything is, and the category does no work. And thus Ely himself acknowledges the substantive nature of the Thirteenth Amendment's prohibition. ${ }^{96}$

So Ely needs an argument for why a generation that can write a clear, judicially enforceable constitutional prohibition against a practice that is widely regarded as monstrous, should stay its hand. "Because that hand will some day die and rule from the grave" is not a very persuasive argument if the current generation is firmly convinced that its position is the correct one. After all, the whole point of enshrining substantive values into a constitution is to prevent a future, less enlightened generation from abandoning those values, perhaps in a time of peril when the People's leaders claim that they must be sacrificed to preserve other substantive values, typically security.

Ely in fact credits exactly this argument when it comes to freedom of expression. Adopting what my colleague Vincent Blasi calls the "pathological perspective" on the First Amendment, ${ }^{97}$ Ely argues against ad hoc balancing approaches to free speech, even forms of balancing that place a nominally heavy burden on the government censors. "[A] specific harm test of any sort," he writes, "is likely to erode in times of perceived crisis." 98 In this account, the categorical approach to the First Amendment—indeed the First Amendment itself—-serves as a kind of Ulysses contract: In calm times, the People bind themselves to the mast of robust protection for free expression, calculating that in subsequent times of crisis they will be tempted

\footnotetext{
${ }^{96}$ See id..

${ }^{97}$ Vincent Blasi, The Pathological Perspective and the First Amendment, 85 Colum. L. Rev. 449 (1985).

${ }^{98}$ Ely, supra note 1, at 114 (emphasis in original).
} 
to take measures to suppress speech that they would eventually come to regret when the crisis passes. $^{99}$

The argument is a good one, but it is hard to see that the phenomenon just described is confined to matters of free speech. Constitutional democracies appear to go through periodic paroxysms during which they temporarily lose faith in their fundamental values. During these periods, the People are prone to xenophobia, to suppression of dissident speech, and more generally to exaggerating the degree to which maintaining order requires the sacrifice of liberty. $^{100}$

Ah yes, Ely would say, but these paroxysms have tended to fit the Carolene Products pattern: Germans, Japanese, Communists, and Muslims are targeted in the relevant periods; and the rights sacrificed are procedural in that they involve either free expression or the due process protections of the criminal courts. A constitution which enshrines only procedural values of the representation-reinforcing sort will thus suffice to meet these challenges. We don't need general substantive constitutional protections. ${ }^{101}$

\footnotetext{
${ }^{99}$ I put to one side the oddity that constitutions are usually written in times of tumult — such as in the wake of a revolution - rather than in calm times. I think it fair to say that whatever the tenor of the times, constitution writers, if their work is to be regarded as ultimately successful, will view themselves as calmly writing for the ages, even as they compromise some first principles to accomplish relatively shortterm political aims.

${ }^{100}$ For examples memorialized in the U.S. Reports, see Schenck v. United States 249 U.S. 47 (1919) (sustaining a conviction under the Espionage Act of 1917 for the mailing of a pamphlet urging readers to resist conscription through lawful means); Meyer v. Nebraska, 262 U.S. 390 (1923) (invalidating a World War I era prohibition on the teaching of German); Korematsu v. United States, 323 U.S. 214 (1944) (upholding an Army order excluding persons of Japanese descent from the western United States); Hamdi v. Rumsfeld, 124 S. Ct. 2633 (2004) (rejecting the government's claim that the courts must grant complete deference to a Presidential assertion that a U.S. citizen is an unlawful enemy combatant, and therefore subject to indefinite detention).

${ }^{101}$ Cf. Ely, supra note 1, at 181-82 (arguing that a representation-reinforcing approach to constitutionalism would prohibit a genocidal regime, which could only come to power in a democracy by victimizing a discrete and insular minority). For an earlier expression of the view that substantive and formal safeguards go together so that a regime that satisfied the desiderata of formal justice would be largely immune from substantive injustice, see generally Lon Fuller, The Morality of Law (1964).
} 
Maybe we don't, I'm tempted to reply, but where's the harm? Why not prohibit slavery against the off chance that in a future less enlightened age someone tries to enslave our debtor grandchildren? Or, if you think that example preposterous—as easily dismissed as Dean Wellington's hypothetical law forbidding the removal of gall bladders ${ }^{102}$ - how about a constitutional amendment categorically prohibiting the torture of any person, even if ostensibly authorized by the President and undertaken for the purpose of obtaining information needed to avert grave harm to or the death of innocents? There may be reasons to think such a substantive prohibition unwise, ${ }^{103}$ but, unfortunately, the claim that it is unnecessary cannot be seriously maintained. ${ }^{104}$

I think Ely's answer to this example would have to be that the People oughtn't write their most cherished substantive values into the constitution because more often than not they will end up enshrining values that the People will later come to reject—not just in times of crisis but in their considered sober judgment. For every prohibition of slavery, the People will enact a Prohibition on alcohol and a Contracts Clause, which will then have to be either repealed or

\footnotetext{
${ }^{102}$ See id. at $182-83$.

${ }^{103}$ For example, some people think torture should be permitted when it is calculated to ascertain where a known captive terrorist has planted a ticking bomb. See, e.g., Alan M. Dershowitz, Why Terrorism Works: Understanding the Threat, Responding to the Challenge (2002) (arguing that non-lethal torture should be permissible to extract information in order to prevent an imminent attack). For criticism of this view, see David Cole, The Priority of Morality: The Emergency Constitution's Blind Spot, 113 Yale L.J. 1753, 1794 -95 (2004). To be clear, I am one of the critics. In my view, categorical prohibitions on torture are justified by the risk that guardians of public safety will, if given the formal legal power to torture, come to think that they hear ticking bombs everywhere. Cf. H.C. 5100/94, Pub. Comm. Against Torture in Isr. v. Gov't of Israel, 53(4) P.D. 817 (holding that physical coercion is impermissible under Israeli law, even in the ticking bomb scenario).

${ }^{104}$ For an indication of the extent to which torture is considered a valid (and perhaps valuable) tool in United States anti-terrorism policy, see Bybee Memo, supra note 39, at 31-39 (discussing the ways in which the President's role as Commander in Chief can trump international treaties and domestic statutes). Inter alia, The Bybee Memo also argues that the Torture Victims Prevention Act includes a specific intent requirement which can be manipulated to immunize interrogators from prosecution, even if the defendant "knows" that severe pain will result from his actions, id. at 3-4, and employs a very narrow definition of torture, one that excludes many methods of inflicting severe pain and distress. Id. at 5-13.
} 
construed out of existence. ${ }^{105}$ You may think with utter confidence that the value you hold-the immorality of abortion, say, or the immorality of substantial government restrictions on abortion in the early portions of pregnancy—ought to be permanently enshrined against backsliding, but when you reflect on the fact that earlier generations thought the same way not only about values you don't now hold but ones you find positively repugnant (such as slavery), you will hesitate to enshrine your chosen value in a constitution.

Whether it is practical to expect people to entertain this sort of doubt about their most deeply held values is itself doubtful on pragmatist grounds. As Holmes was fond of saying, what it means deeply to hold a value (or more generally, a belief of any sort) is that one "can't help" but believe in it. ${ }^{106}$ And if you can't help but believe some substantive normative propositionthat slavery or torture is always wrong, say—you probably also can't help but believe that a future generation that comes to disbelieve in this proposition will simply be mistaken; you will see that potential departure as a fall from grace rather than as progress. If someone tells you that over the long run, the values the People have tended to enshrine in the Constitution are ones that you now regard as misguided or immoral, you will take this cautionary tale as a reason to be very sure that you only work to enshrine in the Constitution your most deeply cherished values — only those values that you really can't help but believe. But that just means that you may try to entrench fewer substantive values than you would have tried to entrench otherwise; the caution is unlikely to lead you to follow Ely's austere advice that you entrench no substantive values in the Constitution.

\footnotetext{
${ }^{105}$ See Ely, supra note 1, at 100. As Rawls observes in a related context, this sort of claim "hinges on fundamental questions about how political institutions actually work and rests on our rough knowledge of these things." Rawls, supra note 12, at 424.

${ }^{106}$ Letter from Oliver Wendell Holmes to John Gray (Sept. 3, 1905), quoted in Sheldon Novick, Honorable Justice: The Life of Oliver Wendell Holmes 283 (1989).
} 
And that's probably just fine with Ely. In saying (or at least strongly implying) that an ideal constitution would be wholly procedural, Ely was not saying that we should cast aside the Constitution we have as impure. He thought our actual Constitution, which by his own reckoning includes at least a handful of bona fide substantive provisions, was nonetheless a basically procedural document. Ely's point about constitution writing is probably best understood as rhetorical: If he can make plausible the claim that even the People in their capacity as constitution writers, armed with the full legitimacy of a super-majoritarian mandate, ought not entrench what they firmly regard as fundamental substantive values, then the much weaker claim that unelected judges armed only with ambiguous text adopted in different circumstances ought not interpret that text to entrench what a bare majority of them regard as substantive values, should seem like a no-brainer.

In fact, however, Ely's argument for limiting judicial review to representation reinforcement has always been controversial, not so much because he fails to make a plausible case for excluding substantive values from the ideal constitution, but because it is difficult to distinguish clearly between substantive and procedural values. Our most socially divisive constitutional issues - including abortion, affirmative action, church-state separation, free speech rights involving the flag, gay rights, and racial profiling of suspected terrorists — all involve either the sorts of constitutional provisions that expressly qualify for special judicial solicitude under the Carolene Products framework, or, as in the case of abortion, that can be readily rerationalized in terms of such provisions. ${ }^{107}$ Ely is thus left in the uncomfortable position of either allowing that a representation-reinforcing theory of judicial review excludes nothing and is thus indistinguishable from a fundamental values approach, or of having to declare by seeming

${ }^{107}$ See Ruth Bader Ginsburg, Speaking in a Judicial Voice, 67 N.Y.U. L. Rev. 1185, 1199-1207 (1992) (arguing that the abortion right should have been rooted in the Equal Protection Clause). 
fiat that some set of rights that can plausibly be rooted in equality are really about liberty and thus impermissibly substantive.

That is by far the most commonly made argument against Ely's theory of judicial review. And if Ely's argument must stand or fall based upon his ability to articulate firm criteria for cleanly distinguishing between substantive and procedural values, the argument seems devastating. But I want to suggest that understanding Ely's project as interpretive in the way I have described it provides him with at least a partial answer.

Coherentism, by its nature, is always a matter of judgment and degree rather than one of binary on/off criteria. To say that some interpretive principle makes the relevant data-here, the constitutional text, its history, doctrine, and so forth- "hang together" better than some other interpretive principle, is to say something that cannot be demonstrated in any remotely rigorous fashion. It is an appeal to the listener's sensibilities. It aims to induce in the listener a reaction of the form: "Oh, now I understand these cases," (or the point of this provision, or whatever is being interpreted). And despite the difficulty of drawing sharp lines between substantive and procedural values, Democracy and Distrust repeatedly has this effect, at least on this reader.

Re-reading Democracy and Distrust in preparation for this Symposium, I expected to find fun, punchy prose setting forth Ely's theoretical framework, and I did. But I was also repeatedly struck by Ely's insights into practical questions of doctrine. Three examples should suffice to show how, with an economy of words sadly missing from today's law reviews, Ely could apply his general theory to generate a fresh and compelling perspective on seemingly wellworn subjects. 
First, and most central to Ely's project, is his treatment of the Warren Court's decisions in Baker v. Carr, ${ }^{108}$ Reynolds v. Sims, ${ }^{109}$ and their progeny. After canvassing the usual reasons why departures from the principle of one-person, one-vote are consistent with various reasonable versions of democratic theory, ${ }^{110}$ Ely observes that once it decided to enter the political thicket of entertaining apportionment claims, considerations of administrability led the Court to adopt "what seemed on the surface the more intrusive rule on the theory that it would be less intrusive in practice."111 He then draws a parallel to two Warren Court decisions involving criminal procedure that exhibit the same pattern, ${ }^{112}$ and concludes, in characteristically pithy style, that "[s]ometimes more is less." 113 Seeing all this masterfully accomplished in just a few lines of prose, one is tempted to add that sometimes less is more.

A second example is buried within Ely's excellent effort to make sense of and refine the various formulations offered in the cases and academic literature of the criteria that render some, but not most government classifications suspect. ${ }^{114}$ In unpacking the idea of "prejudice," Ely writes that the proper inquiry should not focus initially on "whether there exists unjustified widespread hostility toward the group disadvantaged by the official act in issue . . but simply whether there exists widespread hostility."115 His very next example, however, seems to (but only seems to) belie the point. He writes that "burglars are certainly a group toward which there is widespread societal hostility, and laws making burglary a crime certainly do comparatively

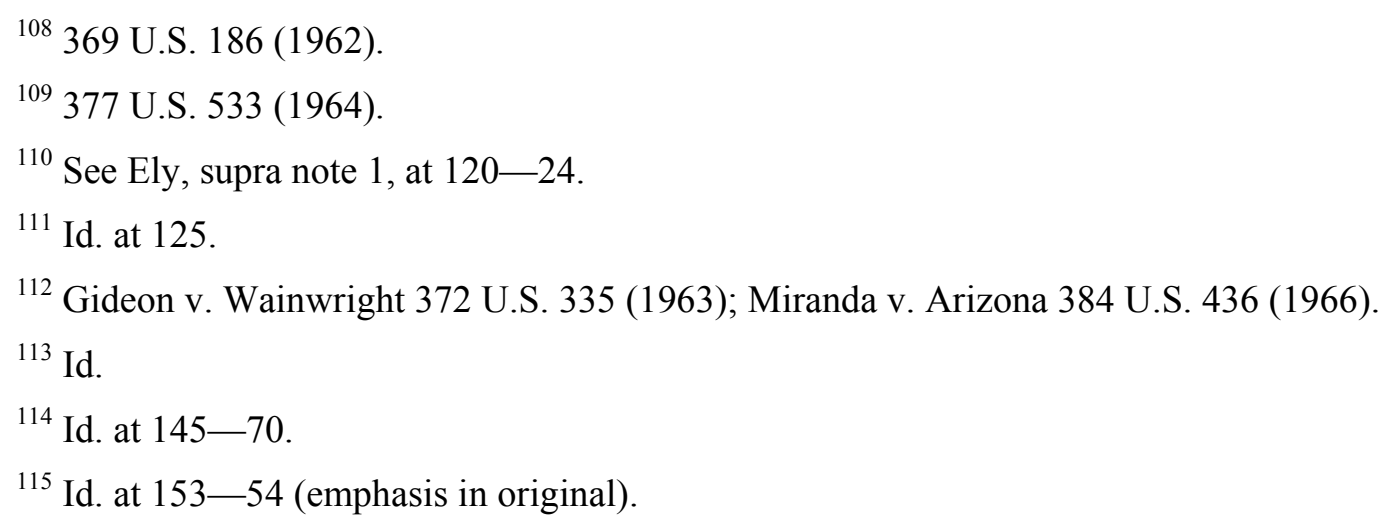


disadvantage burglars." ${ }^{116}$ Does Ely mean to suggest that burglars ought to be a suspect class? His answer is that it doesn't matter. "There is so patently a substantial goal here, that of protecting our homes by penalizing those who break and enter them, and the fit between that goal and the classification is so close, that whatever suspicion such a classification might ... engender is allayed so immediately it doesn't even have time to register." ${ }^{\prime 17}$

Reading this passage, I couldn't help but think of Romer v. Evans, ${ }^{118}$ in which, without holding that sexual orientation is a suspect classification, the Court invalidated a Colorado constitutional provision that prohibited the state or any of its subdivisions from protecting sexual minorities against discrimination on the basis of sexual orientation. In a nasty dissent, Justice Scalia ridiculed the majority's notion that the Colorado provision offended the federal Constitution simply because it betrayed an illicit "animus" against sexual minorities. Absent some form of heightened scrutiny, Justice Scalia asserted, this category made no sense; he likened the animus expressed by the challenged provision to the (obviously permissible) animus towards murderers that prohibitions on murder exhibit. ${ }^{119}$

Ely's example suggests a response. He reminds us that the real issue in any equal protection case is, duh, whether people have been the victims of unfair prejudice. We know that, one way or another, the Court will uphold a burglary prohibition against a challenge by the class of burglars, but it hardly follows that the state can do anything it wishes to burglars. If, for example, persons convicted of burglary were barred from participating in a broad array of social programs, the suspicion engendered by the classification would not, as in the case of a burglary

\footnotetext{
${ }^{116}$ Id. at 154.

${ }^{117}$ Id.

${ }^{118} 517$ U.S. 620 (1996).

${ }^{119}$ Id. at 644 (Scalia, J., dissenting).
} 
prohibition itself, be immediately allayed. The imposition of broad disabilities on burglars might or might not be permissible, but it does not follow from the fact that the state can prohibit burglary that it can impose any disabilities it chooses on burglers as a class.

Likewise in Romer, it does not follow from the fact (which is what it was in 1996) that the state can prohibit homosexual conduct, that the state can impose any disability it wishes on sexual minorities who engage in or are prone to engage in that conduct. Ely thus provides a way of seeing what is generally thought to be a defect in the Romer opinion-its failure to employ either conventional rational basis or heightened scrutiny—as an arguable virtue: it focuses directly on the core equal protection question, whether unfair prejudice (or animus) is at work. Where it may have once seemed a devastating rebuttal to Justice Kennedy's majority opinion to point out that it offers no way to distinguish between homosexuals and burglars, the relevant passage of Democracy and Distrust shows why there may be no need to draw such a distinction.

As my third and final example of the retail level insights that Ely serves up in Democracy and Distrust, I would point to his call for a revival of the nondelegation doctrine, ${ }^{120}$ which nicely illustrates the reach and inter-connectedness of his thinking about constitutional law. Ely wants to revive nondelegation doctrine because he thinks that Congressional efforts to avoid accountability should not be rewarded. That, of course, is a principal leitmotif of his work on the war powers. Although his views of war powers are subtle and complex in their own right, they are rooted in the same democratic instinct that underwrites his interest in reviving nondelegation

\footnotetext{
${ }^{120}$ See Ely, supra note 1, at 133-34. For what it is worth, I tend to think Ely underestimates the degree to which, even a nominally forgiving test such as the "intelligible principle" requirement, could, if taken seriously by the courts, be used to throw sand in the gears of the administrative state. Ely says "that the nondelegation doctrine, even at its high point, never insisted either on more detail than was feasible or that matters be settled with more permanence than the subject matter would allow." Id. at 133. I would respond that the modern (near-)death of nondelegation doctrine owes to the Justices' quite appropriate recognition that they are poorly situated to say how much detail is feasible or how much permanence a given subject matter allows.
} 
doctrine. Condemning Congress's performance during the Vietnam War, Ely writes: "It was Congress's duty to exercise independent judgment. That's why we have separate branches. That's why the war power is vested in Congress." ${ }^{21}$ These words could hardly be more relevant than today, when Senator (and Democratic Party Presidential nominee) John Kerry defends his October 2002 vote to authorize President Bush to use the armed forces of the United States in Iraq, on the ground that Congress needed to give the President the power to decide whether to make war so as to strengthen his hand in diplomacy. ${ }^{122}$

The foregoing examples — and many more I might cite-demonstrate Ely’s enormous ability to cut to the heart of constitutional questions. His sure-footed capacity to bring the general concept of democracy to bear on a wide variety of vexing problems leaves the reader reassured that even if he cannot come up with a bright line between separating substantive from procedural values in the abstract, he will usually know it well enough when he sees it.

\section{Conclusion}

The genius of Democracy and Distrust is its simplicity. Judicial review, to be legitimate in a constitutional system that highly values rule by the People, must be sufficiently cabined to allow decisions of democratically accountable bodies to play the leading role in the day to day business of government. In principle, one could look to text, original understanding, or some

${ }^{121}$ John Hart Ely, War and Responsibility: Constitutional Lessons of Vietnam and its Aftermath 30 (1993).

122 See Jody Wilgoren, Kerry Says his Vote on Iraq Would Be the Same Today, N.Y. Times, Aug. 10, 2000, at A18 ("I believe it's the right authority for a president to have."); see also Michael C. Dorf, Kerry Stands by His Iraq War Vote, and Stands, With Bush, Against Constitutional Principles, FindLaw's Writ (Aug. 18, 2004), at http://writ.corporate.findlaw.com/dorf/20040818.html (arguing that both Kerry and Bush hold a theory of Executive Power that is inconsistent with the spirit of the Constitution's grant to Congress of the power to declare war); Louis Fisher, Congressional Abdication in War and Spending (2000). 
other set of materials for limiting principles, but Ely's principle of representation reinforcement more directly ties the solution to the problem. If our aim is to limit judicial review so that we preserve democracy, what could be better than a principle that says that judicial review should be limited to those circumstances in which it preserves democracy?

The fact that representation reinforcement is designed specifically to tackle the countermajoritarian difficulty ${ }^{123}$ puts its rivals at a serious disadvantage, for they must be gerryrigged to be consistent with democracy, whereas Ely's account takes democracy as its starting point. Perhaps because Ely's readers already value democracy, it is easy to miss the fact that Democracy and Distrust expressly provides no persuasive justification for that starting point. Nonetheless, if we see Ely's project as interpretive, coherentist and pragmatic in the same way that other accounts of American constitutionalism are interpretive, coherentist and pragmatic, then the value that the American People place on democracy combines with its role in the constitutional text and the institutional limitations of the judiciary to make his normative case for representation reinforcement a powerful one.

Whether the staying power of Democracy and Distrust owes more to its author's synthetic abilities as a theorist at the wholesale level or to his incisive doctrinal analysis at the retail level is a nice question, but largely beside the point. In a coherentist account like the one Ely offers, insights at the wholesale and retail level mutually reinforce one another. The retail level analysis demonstrates the utility and soundness of the theory, while the theory provides the glue that makes the retail-level analysis hang together. Surely one measure of the greatness of Ely's accomplishment is that even now, when the opinions of the Warren Court, whose work

\footnotetext{
${ }^{123}$ Ely quite rightly denies that his approach is thus circular. See Ely, D\&D, supra note 1, at 102 (“' I ] isn't any more circular than setting out to build an airplane and ending up with something that flies.").
} 
Democracy and Distrust aims to justify, so often read like period pieces, ${ }^{124}$ the book remains fresh, even urgent.

\footnotetext{
${ }^{124}$ I have in mind especially the cases finding that the state's failure to provide free counsel or to waive fees for indigent criminal defendants amounts to discrimination against the poor. See, e.g., Roberts v. LaVallee, 389 U.S. 40, 42 (1967) (per curiam) (stating, in the course of finding a right of an indigent defendant to a free transcript of a preliminary hearing, that "[o]ur decisions for more than a decade now have made clear that differences in access to the instruments needed to vindicate legal rights, when based upon the financial situation of the defendant, are repugnant to the Constitution. "); Douglas v. California, 372 U.S. 353, 355 (1963) (finding that state failure to provide free counsel for direct criminal appeal works "invidious" "discrimination" against the poor). Such decisions from a largely bygone age made plausible, in 1969, Frank Michelman's claim that the Court had found in the Constitution a sate "duty to protect against certain hazards which are endemic in an unequal society . . ." Michelman, supra note 40, at 9 (1969); see also id. at 14-16 (finding Rawls's thought on distributive justice and minimum welfare central to a proper understanding of the relevant Warren Court decisions).
} 